\title{
PENGATURAN KONSEP KEBAHARUAN PRODUK DALAM PENDAFTARAN DESAIN INDUSTRI PADA UNDANG-UNDANG NOMOR 31 TAHUN 2000 TENTANG DESAIN INDUSTRI
}

\author{
Oleh : \\ Lis Julianti ${ }^{1)}$ Emmy Febriani Thalib ${ }^{2)}$ Made Indra Saputra ${ }^{3)}$ \\ 1) 3) Fakultas Hukum Universitas Mahasaraswati Denpasar \\ ${ }^{2}$ STIMIK STIKOM Indonesia \\ Email : $\underline{\text { isjulianti@,unmas.ac.id }{ }^{1)}}$
}

\begin{abstract}
The judge's interpretation of the novelty principle, where the Panel of Judges in industrial design disputes argues that an industrial design can be said to be new if it has undergone a significant change in visual appearance, meaning that the visual appearance of the two objects is very different. If not, then the modification of a product cannot be called new so that it cannot be considered as an industrial design. The problems of this research include: how is the regulation of product novelty in the registration of industrial designs in Law Number 31 of 2000 and how is the legal protection of designers against the concept of novelty of products in the legal system in Indonesia. This type of research used in discussing the problem of this research is normative legal research. The conclusions of this research are as follows: Regulations on Product Newness in the Registration of Industrial Designs in Law Number 31 of 2000, among others, are in Article 9. And legal remedies are contained in Article 54 of Law Number 31 of 2000. Legal protection of designers against the concept of product novelty In the legal system in Indonesia, among others: Preventive protection: This protection is also closely related to the awareness of the owner of the industrial design rights themselves to register their industrial designs in order to get protection from the State. Regressive protection for holders of Industrial Design Rights is protection that is carried out directly to resolve or overcome an event or incident that has occurred in the form of a violation of the right to industrial design.
\end{abstract}

\section{Keywords: Regulations, Product Newness and Industrial Design}

\begin{abstract}
Abstrak
Penafsiran terhadap penerapan prinsip kebaruan (novelty) oleh hakim, dimana Majelis Hakim dalam sengketa desain industri berpendapat bahwa sebuah desain industri dapat dikatakan baru apabila telah mengalami perubahan penampakan visual yang signifikan, artinya penampakan visual kedua benda tersebut menjadi sangat berbeda. Bila tidak, maka modifikasi suatu produk tersebut tidak dapat disebut baru sehingga tidak dapat dianggap sebagai suatu
\end{abstract}


desain industri. Permasalahan penelitian ini antara lain: bagaimanakah Pengaturan tentang Kebaharuan Produk dalam Pendaftaran Desain Industri pada UndangUndang Nomor 31 Tahun 2000 dan bagaimanakah Perlindungan Hukum Pendesain terhadap konsep kebaharuan produk dalam sistem hukum di Indonesia. Jenis penelitian yang dipergunakan dalam membahas masalah penelitian ini adalah penelitian hukum normatif. Simpulan penelitian ini sebagai berikut: Pengaturan tentang Kebaharuan Produk dalam Pendaftaran Desain Industri pada Undang-Undang Nomor 31 Tahun 2000 antara lain dalam Pasal 9. Dan upaya hukum tertuang dalam Pasal 54 Undang-Undang Nomor 31 Tahun 2000. Perlindungan Hukum Pendesain terhadap konsep kebaharuan produk dalam sistem hukum di Indonesia antara lain : Perlindungan preventif : Perlindungan ini juga sangat berkaitan dengan kesadaran dari pemilik hak desain industri itu sendiri untuk mendaftarkan desain industrinya agar mendapatkan perlindungan dari Negara. Perlindungan refresif bagi pemegang Hak Desain Industri adalah perlindungan yang dilakukan secara langsung untuk menyelesaikan atau memanggulangi suatu peristiwa atau kejadian yang telah terjadi berupa pelanggaran hak atas desain industri.

\section{Kata Kunci : Pengaturan, Kebaharuan Produk dan Desain Industri}

\section{A. Pendahuluan}

Undang-Undang Desain Industri yang Indonesia miliki pada dasarnya hanya menelan secara utuh ketentuan yang terkandung dalam pasal Perjanjian TRIPs tentang Desain Industri, hal ini terlihat dari ketentuan Pasal 2 Undang-Undang Desain Industri yang mengemukaan desain industri yang dapat memperoleh perlindungan meliputi :

1. Hak Desain Industri diberikan untuk desain industri yang baru.

2. Desain Industri dianggap baru apabila pada tanggal penerimaan, desain industri tersebut tidak sama dengan pengungkapan yang telah ada sebelumnya.

3. Pengungkapan sebelumnya, sebagaimana dimaksud dalam ayat (2) adalah pengungkapan desain industri yang sebelum (i) tanggal penerimaan; (ii) tanggal prioritas apabila permohonan diajukan dengan hak prioritas; dan (iii) telah diumumkan atau digunakan di Indonesia atau di luar Indonesia

Adapun maksud dari UndangUndang Desain Industri tersebut mengenai pengungkapan adalah pengungkapan melalui media cetak atau elektronik, termasuk juga keikutsertaan dalam suatu pameran. Menurut pengertian Pasal 2 aquo, dapat disimpulkan bahwa suatu desain industri akan dianggap baru apabila pada tanggal penerimaan desain yang didaftarkan tersebut tidak sama dengan 
Jurnal Hukum Saraswati (JHS), Volume. 03, Nomor 02, (2021) FAKULTAS HUKUM UNMAS DENPASAR ISSN (Cetak) : 2715-758X ISSN (Online): 2720-9555

Doi: https://doi.org/10.36733/jhshs.v2i2 httns://e-iournal.unmas.ac.id/index.vho/JHS

110

pengungkapan yang telah ada ada sebelumya. Ketentuan ini sama sebelumnya. Dengan demikian sekali belum memberikan sebuah pengungkapan terlebih dahulu oleh kepastian yang jelas mengenai prinsip pendesain akan menghilangkan unsur kebaruan. Juga bahwa Undang-Undang Desain Industri tidak menerapkan pendekatan orisinalitas, melainkan lebih menekankan apakah suatu desain industri baru atau tidak. ${ }^{1}$

Adapun kemudian muncul sebuah permasalahan yang mendasar terkait perlindungan desain industri di Indonesia, karena tidak ada definisi dan pengertian jelas yang diberikan oleh Undang-Undang Desain Industri maupun di peraturan perundangundangan lain yang berlaku terkait bagaimana prinsip kebaruan yang digunakan, apakah kemudian yang menjadi indikator desian industri tersebut dapat dikatakan baru, karena dilihat dari pengertian yang diberikan oleh Pasal 2 Undang-Undang Desain Industri hanya bertitik tolak bahwa pada tanggal penerimaan pendaftaran, desain industri yang didaftarkan tidak sama dengan pengungkapan yang telah

1 Hendra Setiawan, 2008, Penilaian Kebaruan Menurut Hukum Desain Industri Indonesia(online),http://www.hukumonline.co $\mathrm{m} /$ berita/baca/hol20446/penilaian-kebaruanmenurut-hukumdesain-industri-indonesia, (27 October 2020)

Ketidak tegasan Undang-Undang Desain Industri dalam mengatur metode pendekatan untuk menilai unsur kebaruan telah menimbulkan ketidakpastian hukum. Tidak ada satupun ketentuan dalam UndangUndang Nomor 31 Tahun 2000 tentang Desain Industri yang mencantumkan penjelasan mengenai prinsip dari kebaruan (Novelty) dari sebuah desain indutri yang terdaftar, sehingga dalam prakteknya penafsiran terhadap ketentuan pasal tersebut diserahkan kepada hakim dalam proses pengadilan jika terjadi sengketa.

Sebagai contoh dalam perkara gugatan pembatalan desain industri Mesin Gergaji type STIHL 070 oleh Precision Tooling S.p.A. berkedudukan di Italia (sebagai penggugat), v. Andreas STIHL AG \& Co.KG, berkedudukan di Deutschland Republik Federasi Jerman (DE) (sebagai tergugat), karena dianggap tidak baru. Kedua belah pihak telah 
Jurnal Hukum Saraswati (JHS), Volume. 03, Nomor 02, (2021) FAKULTAS HUKUM UNMAS DENPASAR ISSN (Cetak) : 2715-758X ISSN (Online): 2720-9555

Doi: https://doi.org/10.36733/jhshs.v2i2 httns://e-iournal.unmas.ac.id/index.phv/JHS

111

menggunakan kuasanya masing- Tergugat) karena desain industri masing. ${ }^{2}$

Diperkara tersebut terdapat Karung Plastik Anti Slip yang telah terdaftar dianggap tidak baru. Pada penafsiran terhadap penerapan prinsip sengketa ini terdapat penafsiran kebaruan (novelty) oleh hakim, dimana Majelis Hakim dalam sengketa ini berpendapat bahwa sebuah desain industri dapat dikatakan baru apabila telah mengalami perubahan terhadap penerapan prinsip kebaruan (novelty) oleh hakim, dimana Majelis Hakim dalam sengketa ini berpendapat bahwa sebuah desain industri dapat dikatakan baru apabila telah penampakan visual yang signifikan, artinya penampakan visual kedua benda tersebut menjadi sangat berbeda. Bila tidak, maka modifikasi suatu produk tersebut tidak dapat disebut baru sehingga tidak dapat dianggap sebagai suatu desain industri.

Berbeda dengan pertimbangan hukum pada uraian sengketa desain industri Mesin Gergaji tipe STIHL 070 oleh Precision Tooling S.p.A. berkedudukan di Italia (sebagai penggugat), v. Andreas STIHL AG \& Co.KG, berkedudukan di Deutschland Republik Federasi Jerman (DE) (sebagai tergugat), dalam perkara gugatan pembatalan desain industri Karung Plastik Anti Slip antara PT. Boma Internusa (sebagai Penggugat) v. PT PPEN Rajawali Nusantara (sebagai

2 Putusan Pengadilan Niaga Jakarta Pusat No. 02/Desain Industri/2004/ PN.Niaga.Jkt.Pst mengalami perubahan atau modifikasi maupun penambahan dari desain sebelumnya yang telah ada, berdasarkan penafsiran ini suatu desain industri dapat dikatakan baru tanpa perlu ada perubahan signifikan yang terjadi pada desain industri sebelumnya.

Kedua putusan pengadilan tersebut telah terjadi sebuah ketidakpastian hukum, norma kabur dimana dalam putusan pertama, penerapan prinsip kebaruan (novelty) menggunakan prinsip bahwa desain industri dapat dikatakan baru apabila telah mengalami perubahan penampakan visual yang signifikan, artinya penampakan visual kedua benda tersebut harus memiliki perbedaan yang sangat signifikan agar bisa disebut sebagai desain yang memiliki unsur kebaruan. Sedangkan 
Jurnal Hukum Saraswati (JHS), Volume. 03, Nomor 02, (2021) FAKULTAS HUKUM UNMAS DENPASAR ISSN (Cetak) : 2715-758X ISSN (Online): 2720-9555

Doi: https://doi.org/10.36733/jhshs.v2i2 httns://e-iournal.unmas.ac.id/index.vho/JHS

112

dalam putusan kedua menggunakan penerapan prinsip kebaruan (novelty) yang berbeda yakni desain industri dapat dikatakan baru apabila desain tersebut telah mengalami perubahan atau modifikasi meskipun perubahan tersebut bukan merupakan perubahan yang signifikan, itu artinya bahwa masih ada kemiripan visual dengan desain sebelumnya.

Atas dasar hal tersebut penulis tertarik untuk mengadakan penelitian dengan mengambil judul : "Pengaturan Konsep Kebaharuan Produk Dalam Pendaftaran Desain Industri Pada Undang-Undang Nomor 31 Tahun 2000 Tentang

\section{Desain Industri”}

Beberapa permasalahan yang dikemukakan yaitu: 1) Bagaimanakah Pengaturan tentang Kebaharuan Produk dalam Pendaftaran Desain Industri pada Undang-Undang Nomor 31 Tahun 2000 ?, 2) Bagaimanakah Perlindungan Hukum Pendesain terhadap konsep kebaharuan produk dalam sistem hukum di Indonesia?

\section{B. Metode Penelitian}

$$
\text { Jenis penelitian yang }
$$

dipergunakan dalam penyusunan penelitian ini adalah penelitian hukum normatif. Menurut Bambang Sunggono, dalam bukunya metodelogi penelitian hukum mengatakan:

Penelitian hukum normatif disebut juga penelitian hukum teoritis atau dogmatik, karena tidak mengkaji pelaksanaan atau implementasi hukum, penemuan hukum dalam perkara pidana ataupun perdata, sistematik hukum, taraf sinkronisasi hukum, perbandingan hukum dan sejarah hukum. Dalam penelitian ini yang dimaksud dengan penelitian hukum adalah penelitain hukum yang bersifat akademis yang didalamnya terkandung sifat normatif dan doktrinal untuk menjawab berbagai permasalahan yang diajukan. ${ }^{3}$

\section{Pembahasan}

1. Pengaturan tentang Kebaharuan Produk dalam Pendaftaran Desain Industri pada Undang-Undang Nomor

\section{Tahun 2000}

Kebaharuan didefinisikan sebagai suatu perubahan (ide besar) dalam sekumpulan informasi yang berhubungan diantara masukan dan luaran. Dari definisi tersebut didapatkan dua hal yakni kebaharuan proses dan kebaharuan produk. Hal tersebut yang membedakannya dengan

${ }^{3}$ Bambang Sunggono, 2003, Metodelogi Penelitian Hukum, PT Raja Grafindo Persada, Jakarta, hal.41. 
Jurnal Hukum Saraswati (JHS), Volume. 03, Nomor 02, (2021) FAKULTAS HUKUM UNMAS DENPASAR ISSN (Cetak) : 2715-758X ISSN (Online): 2720-9555

Doi: https://doi.org/10.36733/jhshs.v2i2 httns://e-iournal.unmas.ac.id/index.vho/JHS

113

invensi atau temuan yang merupakan suatu gagasan atau model dari pengembangan suatu produk ata proses (solusi masalah), yang dalam pengertian ekonomi merupakan bagian kebaharuan yang bila produk atau prosesnya ditingkatkan, yang selanjutnya menjadi awal dari proses penjualan di pasar. Kebaharuan baik produk maupun proses merupakan suatu perubahan pada sekumpulan informasi yang berhubungan diantara masukan dan luaran yang terkait dengan upaya meningkatkan atau memperbaiki sumber daya yang ada, memodifikasi untuk menjadikan sesuatu bernilai, menciptakan hal-hal baru dan berbeda, merubah suatu bahan menjadi sumber daya dan menggabungkan sumber daya-sumber daya menjadi suatu konfigurasi baru yang lebih produktif, baik secara langsung maupun tidak langsung yang dipengaruhi oleh kepastian (untung/rugi) atau proses waktu melaksanakanya, dalam rangka meraih keunggulan kompetitif. ${ }^{4}$

\footnotetext{
${ }^{4}$ Suryana, 2011, Kewirausahaan: Pendekatan Karakteristik Wirausahawan Sukses, Kencana Perdana Media Group, Jakarta, hal. 23
}

Kebaharuan produk dijalankan perusahaan untuk menciptakan produk baru yang bertujuan untuk menyesuaikan dengan selera konsumen dan dapat meningkatkan penjualan. Dengan demikian dapat dikatakan bahwa bertambah banyaknya barang yang ditawarkan pada konsumen dan ditunjang dengan arus informasi tentang produk yang mudah diperoleh, menyebabkan mereka semakin selektif dalam membeli suatu barang, baik dalam kualitas, desain corak, warna maupun harganya. Konsep inovasi produk yaitu:

a. Keinovatifan : adalah fikiran tentang keterbukaan untuk gagasan baru sebagai sebuah kultur perusahaan.

b. Kapasitas untuk berinovasi: kemampuan perusahaan untuk mengunakan atau menerapkan gagasan, proses atau produk baru secara berhasil. ${ }^{5}$

Penjelasan dalam UndangUndang Nomor 31 tahun 2000 tentang Desain Industri maupun di peraturan perundang-undangan lain yang berlaku terkait bagaimana prinsip kebaruan yang digunakan, apakah kemudian

\footnotetext{
${ }^{5}$ Wahyono, 2002, Orientasi Pasar dan Inovasi: Pengaruhnya Terhadap kinerja Pemasaran, Jurnal Sains Pemasaran Indonesia, Vol. 1, No.1, 2002, hal. 16
} 
Jurnal Hukum Saraswati (JHS), Volume. 03, Nomor 02, (2021) FAKULTAS HUKUM UNMAS DENPASAR ISSN (Cetak) : 2715-758X ISSN (Online): 2720-9555

Doi: https://doi.org/10.36733/jhshs.v2i2 httns://e-iournal.unmas.ac.id/index.phv/JHS

114

yang menjadi indikator desian industri tersebut dapat dikatakan baru, karena dilihat dari pengertian yang diberikan oleh Pasal 2 Undang-Undang Desain Industri hanya bertitik tolak bahwa pada tanggal penerimaan pendaftaran, desain industri yang didaftarkan tidak sama dengan pengungkapan yang telah ada sebelumya. Ketentuan ini sama sekali belum memberikan sebuah kepastian yang jelas mengenai prinsip kebaruan dari desain tersebut.

Kekaburan norma UndangUndang Desain Industri dalam mengatur metode pendekatan untuk menilai unsur kebaruan telah menimbulkan ketidakpastian hukum. Tidak ada satupun ketentuan dalam Undang-Undang Nomor 31 Tahun 2000 tentang Desain Industri yang mencantumkan penjelasan mengenai prinsip dari kebaruan (Novelty) dari sebuah desain indutri yang terdaftar, sehingga dalam prakteknya penafsiran terhadap ketentuan pasal tersebut diserahkan kepada hakim dalam proses pengadilan jika terjadi sengketa.

Pasal 2 ayat (2) Undang-Undang Nomor 31 Tahun 2000 tentang Desain Industri sebagai dasar pemberlakukan hukum desain industri di Indonesia menyatakan bahwa desain industri diangap baru apabila pada tanggal penerimaan permohonan, desian industri tidak sama dengan pengungkapan yang telah ada sebelumnya. Pengungkapan sebelumnya yang dimaksud ialah pengungkapan desain industri sebelum tanggal penerimaan atau tanggal prioritas telah diumumkan atau digunakan di Indonesia atau di luar Indonesia. Pengungkapan yang dimaksud dalam paragraf sebelumnya dapat diartikan sebagai pengungkapan melalui media cetak atau elektronik termasuk keikutsertaan dalam pameran. Pengaturan keikutsertaan dalam pameran dijelaskan dalam Pasal 3 Undang-Undang Nomor 31 Tahun 2000 tentang Desain Industri.

Dalam ketentuan TRIPs pada article 25, dikatakan bahwa selain elemen kebaruan atau orisinalitas juga ditentuakn bahwa suatu desain yang dapat memperoleh perlindungan harus dapat direproduksi dalam industri (industrial application). Desain harus dapat di aplikasikan pada produk yang berbentuk dua dimensi maupun tiga dimensi. Prosedur permohonan desain industri di Indonesia diawali dengan 
Jurnal Hukum Saraswati (JHS), Volume. 03, Nomor 02, (2021) FAKULTAS HUKUM UNMAS DENPASAR ISSN (Cetak) : 2715-758X ISSN (Online): 2720-9555

Doi: https://doi.org/10.36733/jhshs.v2i2 httns://e-iournal.unmas.ac.id/index.vho/JHS

115

adanya pengajuan permohonan desain industri, sebagaimana yang disyaratkan pada Pasal 18 Undang-Undang Nomor 31 Tahun 2000 tentang Desain Industri untuk memperoleh tanggal penerimaan. Apabila ada keberatan, pemohon diberi kesempatan untuk menyanggah sebelum dilakukan pemeriksan substantif. Setelah melalui proses tersebut, dilakukan pemeriksaan subtantif oleh Ditjen Hak Kekayaan Intelektual (DJHKI). Berdasarkan pemeriksaan subtantif, DJHKI akan menentukan meerima atau menolak keberatan. Apabila keberatan di tolak, maka desain industri akan didaftar dan dilakukan pemberian sertifikat atas desain industri yang terdaftar tersebut. Sejak di terbitkanya Undang-Undang Desain Industri pada tahun 2000, hingga saat ini telah timbul beberapa sengketa dalam desain industri di Indonesia. Dari beberapa sengketa desain industri tersebut, terdapat perbedaan pandangan dalam penerapan prisip kebaruan (novelty).

Didalam sengketa sengketa tersebut terdapat penerapan prinsip kebaruan (novelty) dalam desain industri yang berbeda-beda, ada sengketa desain industri yang mengunakan penerapan prisip kebaruan (novelty) dengan menafsirkan bahwa suatu desain industri tersebut dianggap baru apabila ia memiliki perbedaan dari desain yang telah ada, meskipun perbedaan tersebut hanya sedikit dan pada bagian-bagian tertentu saja, sehingga masih menimbulkan kesan mirip dari desain yang telah ada sebelumnya. Di samping itu juga terdapat penerapan terhadap prisip kebaruan (novelty) yang menafsirkan bahwa desain industri dianggap baru apabila ia memiliki perbedaan yang jauh dah signifikan dari desain yang telah ada terdahulu, sehingga tidak ada unsur kemiripan dengan desain yang telah ada terlebih dahulu.

Dalam Praktiknya di Indonesia masalah penafsiran atas kriteria kebaruan (novelty) tersebut masih berbeda satu dengan lainya baik penafsiran oleh para saksi ahli, Dirjen HKI, maupun oleh aparat penegak hukum, ketidak jelasan dari kriteria kebaruan yang terkandung dalam Undang-Undang Nomor 31 Tahun 2000 tentang Desain Indsutri tentu akan menimbulkan permasalahan dalam penegakan hukum di lapangan. Hal tersebut juga telah menimbulkan 
Jurnal Hukum Saraswati (JHS), Volume. 03, Nomor 02, (2021) FAKULTAS HUKUM UNMAS DENPASAR ISSN (Cetak) : 2715-758X ISSN (Online): 2720-9555

Doi: https://doi.org/10.36733/jhshs.v2i2 httns://e-iournal.unmas.ac.id/index.phv/JHS

116

ketidak pastian hukum dalam proses penegakan hukum. Sehingga peran hakim dalam mengambil keputusan dalam proses pengadilan akan menjadi salah satu faktor yang sangat menentukan.

Norma terkait kebaruan produk dalam pendaftaran desain industri dalam Undang-Undang Nomor 31 Tahun 2000 tentang Desain Industri belum tegas dan jelas masih terjadi perdebatan dalam hal kebaruan sehingga dalam penerapannya/ interpretasi masih memungkinkan terjadi. Sehingga masih perlu kejelasan dan ketegasan tentang kebaruan produk. Mengingat hal-hal tersebut dan berhubung belum diaturnya perlindungan hukum mengenai Desain Industri, Indonesia perlu membuat undang-undang di bidang Desain Industri untuk menjamin perlindungan hak-hak Pendesain dan menetapkan hak dan kewajibannya serta menjaga agar pihak yang tidak berhak tidak menyalahgunakan hak Desain Industri tersebut.

2. Perlindungan

Hukum

Pendesain terhadap konsep

kebaharuan produk dalam sistem hukum di Indonesia
Perlindungan hukum terhadap desain industri sebagai salah satu karya intelektual sangat diperlukan, bukan saja karena untuk kepentingan pendesain semata, akan tetapi dimaksudkan juga untuk merangsang kreatifitas pendesain untuk terus menerus menciptakan desain baru. Tidak semua desain industri yang baru dapat diberikan hak atas desain industri dan perlindungan hukum, Pasal 4 Undang-Undang Nomor 31 Tahun 2000 tentang Desain Industri mengatur tentang desain industri yang bertentangan dengan Peraturan Perundang-undangan yang berlaku, ketertiban umum, agama, dan kesusilaan. Selain itu hak desain industri baru akan diberikan kepada desain industri yang bersifat novelty (baru) dan telah terdaftar.

Hanya desain industri yang mempunyai kebaruan saja yang dapat didaftarkan. Berlakunya UU Desain Industri tentu membawa suatu harapan yang positif bagi proses perlindungan hak desain industri kedepan, hal ini mengingat UU Desain Industri merupakan penyempurnaan dari UU Hak Cipta sebagai perlindungan khusus terhadap pendesain atas hak 
Jurnal Hukum Saraswati (JHS), Volume. 03, Nomor 02, (2021) FAKULTAS HUKUM UNMAS DENPASAR ISSN (Cetak) : 2715-758X ISSN (Online): 2720-9555

Doi: https://doi.org/10.36733/jhshs.v2i2 httns://e-iournal.unmas.ac.id/index.vho/JHS

desain industri yang berkaitan dengan desain yang diproduksi secara massal dengan memberikan kesan estetis berupa pola dua dimensi atau tiga dimensi sehingga memiliki nilai jual yang tinggi.

Dengan adanya perlindungan, pendesain atau pihak yang menerima hak tersebut, memiliki hak eklusif untuk melarang pihak ketiga, tanpa izinnya, guna membuat, menjual atau mengimpor barang-barang yang atau melekatkan desain yang merupakan salinan (copy) atau yang substansinya merupakan salinan dari desain yang dilindungi, asalkan tindakan-tindakan tersebut dilakukan untuk keperluan komersial dan jangka perlindungan paling kurang 10 (sepuluh) tahun. ${ }^{6}$

Indonesia sebagai negara berkembang, perlu memajukan sektor industri dengan meningkatkan kemampuan daya saing. Salah satu adanya daya saing tersebut adalah dengan memanfaatkan peranan Desain Industri yang merupakan bagian dari Hak Kekayaan Intelektual, keanekaragaman budaya yang dipadukan dengan upaya untuk ikut

${ }^{6}$ Achmad Zen Umar Purba, 2005, Hak Kekayaan Intelektual Pasca TRIPs, Alumni, Bandung, hal.78. serta dalam globalissi perdagangan dengan memberikan pula perlindungan hukum terhadap desain industri nasional. $^{7}$

Philipus M.Hadjon membedakan dua bentuk perlindungan hukum yang diberikan oleh Negara yaitu Perlindungan hukum yang preventif dan perlindungan hukum yang represif. Pada perlindungan hukum yang preventif, kepada rakyat diberikan kesempatan untuk mengajukan keberatan (inspraak) atau pendapatnya sebelum suatu Keputusan pemerintah mendapat bentuk yang definitif. Dengan demikian, perlindungan hukum yang preventif bertujan untuk mencegah terjadinya sengketa. Sebaliknya, perlindungan hukum yang refresif bertujuan untuk menyelesaikan sengketa. Sebaliknya, perlindungan hukum bagi rakyat oleh Peradilan Umum di Indonesia termasuk katagori perlindungan hukum menurut represif.

Perlindungan preventif bagi pemegang hak Desain Industri adalah perlindungan yang dilakukan sebelum terjadinya suatu pelanggaran hak desain industri dan tentu saja

${ }^{7}$ Abdul Kadir Muhammad, 2001, Kajian Hukum Ekonomi HKI, Cetakan Pertama, Citra Aditya, Bandung, hal.265. 
Jurnal Hukum Saraswati (JHS), Volume. 03, Nomor 02, (2021) FAKULTAS HUKUM UNMAS DENPASAR ISSN (Cetak) : 2715-758X ISSN (Online): 2720-9555

Doi: https://doi.org/10.36733/jhshs.v2i2 httns://e-iournal.unmas.ac.id/index.phv/JHS

118

perlindungan ini merupakan sebuah bentuk perlindungan yang mengarah pada tindakan yang bersifat pencegahan. Perlindungan ini juga sangat berkaitan dengan kesadaran dari pemilik hak desain industri itu sendiri untuk mendaftarkan desain industrinya agar mendapatkan perlindungan dari Negara.

Perlindungan refresif bagi pemegang Hak Desain Industri adalah perlindungan yang dilakukan secara langsung untuk menyelesaikan atau memanggulangi suatu peristiwa atau kejadian yang telah terjadi berupa pelanggaran hak atas desain industri. Tentunya dengan demikian peranan lebih besar berada pada lembaga peradilan dan aparat penegak hukum lainnya seperti Kepolisian, Pejabat Pegawai Negeri Sipil (PPNS), dan Kejaksaan untuk melakukan penindakan terhadap pelanggaran desain industri.

Dari bentuk perlindungan hukum yang dikemukakan Philipus M. Hadjon Pemerintah membuat peraturan perundang-undangan Nomor 31 tahun 2000 tentang Desain Industri agar dapat tercipta perlindungan dan kepastian hukum bagi masyarakat dalam bidang Desain Industri. Pengaturan Desain Industri dimaksudkan untuk memberikan landasan bagi perlindungan yang efektif terhadap berbagai bentuk penjiplakan, pembajakan, atau peniruan atas Desain Industri.

Dalam HKI dikenal ada dua system pengakuan terhadap suatu hak yakni prinsip deklaratif dan prinsip konstitutif. Sistem konstitutif dalam HKI adalah suatu sistem perlindungan HKI yang mengharuskan adanya pendaftaran untuk mendapatkan perlindungan hak, atau yang dikenal juga dengan sebuah first to file system. Pendaftaran adalah bentuk perlindungan hukum yang menimbulkan kepastian hukum. Untuk itu, menurut sistem konstitutif HKI seseorang dapat diakui dan dilindungi oleh undang-undang jika didaftarkan. Tidak didaftarkan berarti tidak ada pengakuan dan tidak ada perlindungan hukum. ${ }^{8}$

\footnotetext{
8 Abdulkadir, Muhammad, 2007, Kajian Hukum Ekonomi Hak Kekayaan Intelektual, PT. Citra Aditya Bakti, Bandung, hal.157.
} 
Jurnal Hukum Saraswati (JHS), Volume. 03, Nomor 02, (2021) FAKULTAS HUKUM UNMAS DENPASAR ISSN (Cetak) : 2715-758X ISSN (Online): 2720-9555

Doi: https://doi.org/10.36733/jhshs.v2i2 httns://e-iournal.unmas.ac.id/index.vho/JHS

119

\section{Simpulan dan Saran}

Berdasarkan pembahasan yang telah dikemukakan diatas dapat ditarik kesimpulan sebagai berikut:

1. Pengaturan tentang Kebaharuan Produk dalam Pendaftaran Desain Industri pada Undang-Undang Nomor 31 Tahun 2000. Penjelasan dalam Undang-undang Nomor 31 tahun 2000 tentang Desain Industri maupun di peraturan Perundangundangan lain yang berlaku terkait bagaimana prinsip kebaharuan yang digunakan, apakah kemudian yang menjadi indikator desain tersebut dikatakan baru, karena dilihat dari pengertian yang diberikan oleh pasal 2 Undang-undang Desain Industri hanya bertitik tolak pada tanggal penerimaan pendaftaran, desain industry yang didaftarkan tidak sama dengan pengungkapan yang telah ada sebelumnya. Ketentuan ini sama sekali belum memberikan sebuah kepastian yang jelas mengenai prinsip kebaharuan dari desain tersebut.

2. Kekaburan norma Undangundang desain Industri dalam mengatur metode pendekatan untuk menilai unsur kebaharuan telah

menimbulkan

ketidakpastian hukum. Tidak ada satupun ketentuan dalam dalam Undang-undang Nomor 31 Tahun 2000 tentang Desain Industri yang mencantumkan penjelasan mengenai prinsip kebaharuan (Novelty) dari sebuah desain terdaftar, sehingga dalam prakteknya penafsiran terhadap ketentuan pasal tersebut diserahkan kepada hakim dalam proses pengadilan jika terjadi sengketa.

Berdasarkan kesimpulan tersebut diatas dapat disarankan hal-hal sebagai berikut :

1. Perlu adanya perubahan atau amandemen pada beberapa ketentuan yang ada di dalam Undang-Undang Nomor 31 Tahun 2000 tentang Desain Industri. Khususnya ketentuan mengenai "apa yang dimaksud dan disebut" sebagi bentuk kebaruan suatu desain yang akan didaftarkan, yang termasuk juga fokus dari penelitian penulis, kemudian ketentuan mengenai sudut pandang yang seharusnya bukan satu sisi tapi juga seluruh dari desain tersebut, karena 
Jurnal Hukum Saraswati (JHS), Volume. 03, Nomor 02, (2021) FAKULTAS HUKUM UNMAS DENPASAR ISSN (Cetak) : 2715-758X ISSN (Online): 2720-9555

Doi: https://doi.org/10.36733/jhshs.v2i2 httns://e-iournal.unmas.ac.id/index.phv/JHS

kebanyakan desain tersebut adalah seni, jadi ditentukan secara jelas batasannya. Sehingga dimasa depan tidak ada lagi kebingungan mengenai "apa yag disebut baru". Dengan demikian akan menimbulkan kepastian hukum bagi pelaku industri di Indonesia, khususnya pemilik hak desain industri.

2. Perlu adanya penyamaan persepsi atau penafsiran atas kriteria kebaruan (novelty), baik penafsiran oleh para saksi ahli, Dirjen HKI, maupun oleh aparat penegak hukum, sehingga tidak lagi timbul ketidakjelasan dari kriteria kebaruan yang terkandung dalam UndangUndang Nomor 31 Tahun 2000 tentang Desain Industri yang tentu akan menimbulkan permasalahan dalam penegakan hukum di lapangan. Hal ini perlu dilakukan sejalan dengan proses pembenahan atau perubahan dari undang-undang Desain Industri.

\section{Daftar Pustaka}

\section{Buku}

Abdul Kadir Muhammad, 2001, Kajian Hukum Ekonomi HKI,
Cetakan Pertama, Citra Aditya, Bandung. 2007, Kajian Hukum Ekonomi Hak Kekayaan Intelektual, PT. Citra Aditya Bakti, Bandung

Achmad Zen Umar Purba, 2005, Hak Kekayaan Intelektual Pasca TRIPs, Alumni, Bandung.

Bambang Sunggono, 2003, Metodelogi Penelitian Hukum, PT Raja Grafindo Persada, Jakarta.

Putusan Pengadilan Niaga Jakarta Pusat No. 02/Desain Industri/2004/ PN.Niaga.Jkt.Pst

Suryana, 2011, Kewirausahaan: Pendekatan Karakteristik Wirausahawan Sukses, Kencana Perdana Media Group, Jakarta

\section{Jurnal}

Hendra Setiawan, 2008, Penilaian Kebaruan Menurut Hukum Desain Industri Indonesia (online),http://www.hukumonlin e.com/berita/baca/hol20446/penil aian-kebaruan-menurut- 
Jurnal Hukum Saraswati (JHS), Volume. 03, Nomor 02, (2021) FAKULTAS HUKUM UNMAS DENPASAR ISSN (Cetak) : 2715-758X ISSN (Online): 2720-9555

Doi: https://doi.org/10.36733/jhshs.v2i2 httns://e-iournal.unmas.ac.id/index.vho/JHS

hukumdesain-industri-indonesia,

(27 October 2020)

Peraturan Pemerintah Nomor 1 Tahun 2005 tentang pelaksanaan

Wahyono, 2002, Orientasi Pasar dan Undang-undang Nomor 31

Inovasi: Pengaruhnya Terhadap Tahun 2000 tentang Desain kinerja Pemasaran, Jurnal Sains Industri.

Pemasaran Indonesia, Vol. 1, No.1, 2002

\section{Peraturan Perundang-Undangan}

Undang-Undang Republik Indonesia Nomor 31 Tahun 2000 tentang Desain Industri 